\title{
CTP:phosphocholine cytidylyltransferase activity in the preimplantation mouse embryo
}

\author{
E. A. Moon and C. O’Neill* \\ Human Reproduction Unit, Department of Physiology, University of Sydney, Royal North Shore Hospital \\ of Sydney, St Leonards, NSW 2065, Australia
}

\begin{abstract}
Cytidine $5^{\prime}$-triphosphate (CTP):phosphocholine cytidylyltransferase (EC 2.7.7.15) catalyses the synthesis of the active metabolic intermediate cytidine diphosphocholine (which is mainly used in the synthesis of choline-containing phospholipids). It is a rate-limiting reaction in choline phospholipid biosynthesis in many cells. In this study, a microassay is reported for the detection of this enzyme in small numbers of cells. This enzyme was present in mouse oocytes and at all stages during preimplantation development. Enzyme activity was destroyed by boiling but increased with time and number of embryos in the reaction. Activity in two-cell embryos was dependent on $\mathrm{Mg}^{2+}$ but independent of $\mathrm{Ca}^{2+}$ and was enhanced by the addition of $1 \mu \mathrm{g}$ lysophosphatidylethanolamine $\mathrm{ml}^{-1}$ to the reaction mixture. Activity was apparently dependent upon the phosphorylation status of the enzyme since the absence of the phosphatase inhibitor $\mathrm{NaF}$ caused a significant inhibition of activity. The enzyme in oocytes had a specific activity of $2.8 \pm 0.3 \mathrm{fmol}$ cytidine diphosphocholine (CDP-choline) per oocyte $\min ^{-1}$ (mean \pm SEM). The specific activity in two-cell and eight-cell embryos and blastocysts was not different from that of oocytes. Fertilized one-cell embryos had significantly less activity ( $1.4 \pm 0.05 \mathrm{fmol}$ CDP-choline produced per embryo $\min ^{-1}$ ) than other stages studied. Furthermore, the enzyme present in one-cell embryos was not capable of being further activated by the addition of exogenous lysophosphatidylethanolamine to the reaction. The increase in activity from the one-cell to the two-cell stage was not inhibited by $\alpha$-amanitin (an inhibitor of RNA polymerase II), cycloheximide ( $a$ protein synthesis inhibitor) [1-(5-isoquinolinesulfonyl)-2-methylpiperazine, HCl]dihydrochloride ( $\mathrm{H}-7$; a protein kinase inhibitor) and was independent of cell-cycle progression; these results suggest that enzyme activity is independent of transcription, protein synthesis and the action of some kinases, including cell-cycle-dependent kinases. This study provides the first description of cytidylyltransferase in the early mammalian embryo.
\end{abstract}

\section{Introduction}

Choline-containing phospholipids are major components of plasma membranes and intracellular membranes. In addition to their structural roles, they also serve as important substrates for phospholipases and lipases in the generation of important cellular messengers such as diacylglycerol and arachidonic acid metabolites. Choline-containing ether phospholipids can act as potent intracellular and extracellular signals, with the class of compounds known as platelet-activating factor (PAF: 1-o-alkyl2-acetyl-sn-glycero-3-phosphocholine).

Biosynthesis of the choline-containing phospholipids can occur either by the methylation of ethanolamine-containing phospholipids or via an exchange reaction between phosphated glycerols and cytidine diphosphocholine (CDP-choline). This reaction is catalysed by phosphocholine transferase enzymes. In many cell types, the endogenous concentration of CDPcholine is low and may be limiting for phosphatidylcholine

*Correspondence.

Received 16 December 1996. synthesis. CDP-choline biosynthesis is catalysed by cytidine 5'-triphosphate (CTP):phosphocholine cytidylyltransferase (cytidylyltransferase) in the reaction (Vance et al., 1981):

$$
\mathrm{CTP}+\text { cholinephosphate } \leftrightharpoons \mathrm{CDP} \text {-choline }+\mathrm{PP}_{\mathrm{i}}
$$

This reaction is generally rate-limiting for the synthesis of phosphatidylcholine (Sundler and Akesson, 1975) and was shown to be rate-limiting for the production of PAF by both the 'de novo' (Blank et al., 1988) and 'remodelling' (Lee et al., 1990) biosynthetic pathways.

Cytidylyltransferase is a $42 \mathrm{kDa}$ protein that has recently been cloned and sequenced in rats (Kalmar et al., 1990) and mice (Rutherford et al., 1993). It has an open reading frame encoding 367 amino acids. It belongs to a group of enzymes that display amphitrophism (Choy and Vance, 1978); that is, binding of the enzyme to lipids is required for maximal activity.

The preimplantation embryo undergoes an essentially exponential increase in its number of cells during the preimplantation phase (from fertilization to the blastocyst stage). During 
this time, new plasma membrane is required and elaboration of the intracellular membranes also occurs. A high-capacity phosphocholine transferase (which uses CDP-choline as a co-substrate) is present in the embryo throughout the preimplantation phase (Wells and O'Neill, 1994). By observing the incorporation of $\left[{ }^{14} \mathrm{C}\right]$ methyl choline into lipids, Pratt (1980) found that there was a 13-fold increase in phosphocholine synthesis in mouse embryos from the two-cell to the eight-cell stage, suggesting extensive remodelling of membranes. The preimplantation embryo also synthesizes (Wells and O'Neill, 1992, 1994) and releases (O'Neill, 1985) significant quantities of PAF. In addition, $\left[{ }^{\mathrm{I} 4} \mathrm{C}\right.$ methyl choline is incorporated into PAF and released into the medium by embryos in vitro (Wells and O'Neill, 1992).

A membrane choline transporter is present in the early mouse embryo (Van Winkle et al., 1993) and undergoes a 100-fold increase in capacity from the two-cell to the blastocyst stage. Choline kinase activity is present from at least the two-cell stage and increases through to the morula stage (Pratt, 1980). For embryos exposed to exogenous $\left[{ }^{14} \mathrm{C}\right]$ methyl choline (Pratt, 1980), an approximately equal amount of label becomes associated with the choline and the phosphocholine pools within the embryo. This accumulation of $\left[{ }^{14} \mathrm{C}\right]$ methyl choline within embryos indicates that choline transport is not ratelimiting in embryos. Of the choline transported into the embryo, 15-45\% was converted into phosphocholine (Pratt, 1980). By contrast, no accumulation of $\left[{ }^{14} \mathrm{C}\right] \mathrm{CDP}$-choline was observed in the embryos fed $\left[{ }^{14} \mathrm{C}\right]$ methyl choline. A substantial amount of label accumulates in phosphatidylcholine and lysophosphatidylcholine, suggesting that cytidylyltransferase is present within the embryos. The absence of $\left[{ }^{14} \mathrm{C}\right] \mathrm{CDP}$-choline suggests that cytidylyltransferase is the rate-limiting enzyme in the synthesis of choline-containing phospholipids in the preimplantation embryo (Pratt, 1980).

This study investigates the activity of cytidylyltransferase in the unfertilized oocyte and throughout the preimplantation phase of pregnancy, and investigates its identity and the regulation of its activity.

\section{Materials and Methods}

\section{Materials}

$\left[{ }^{14} \mathrm{C}\right]$ methyl phosphorylcholine (specific activity of $1.9 \mathrm{GBq}$ $\mathrm{mmol}^{-1}$ ) and $\left[{ }^{14} \mathrm{C}\right]$ methyl CDP-choline (specific activity of $2.1 \mathrm{GBq} \mathrm{m{ } ^ { - 1 }}{ }^{-1}$ ) were supplied by NEN (Wilmington, DE). L- $\alpha$-oleoyl-lysophosphatidylethanolamine, $\alpha$-amanitin and cycloheximide were purchased from Sigma Chemical Co. (St Louis, MO). The protein kinase inhibitor [1- $(5-$ isoquinolinesulfonyl)-2-methylpiperazine, $\mathrm{HCl}]$, dihydrochloride (H-7) was supplied by LC Laboratories (Woburn, MA).

\section{Embryo collection}

Random-bred Swiss albino mice (Sydney University, NSW), 6-8 weeks old, were superovulated by an i.p. injection of $10 \mathrm{iu}$ pregnant mares' serum gonadotrophin (PMSG; Folligon, Intervet International, Boxmeer) followed $48 \mathrm{~h}$ later by an i.p. injection of $10 \mathrm{iu} \mathrm{hCG} \mathrm{(Chorulon,} \mathrm{Intervet} \mathrm{International).} \mathrm{They}$ were either left unmated or paired with males of proven fertility overnight and the presence of a copulation plug indicated day 1 of pregnancy. Unfertilized oocytes and zygotes were collected $24 \mathrm{~h}$ after hCG administration. The cumulus masses were released from the oviduct into Hepes-buffered human tubal fluid medium (Quinn et al., 1985) supplemented with $3 \mathrm{mg} \mathrm{BSA} \mathrm{ml}^{-1}$ (Hepes-HTF/BSA). Oocytes or zygotes were freed from their cumulus masses by brief exposure to 300 iu hyaluronidase (Sigma Chemical Co.) in Hepesbicarbonate buffered human tubal fluid containing $3 \mathrm{mg}$ BSA $\mathrm{ml}^{-1}$ (HTFM/BSA). They were then thoroughly washed in five changes of Hepes-HTFM/BSA. Embryos at the two-cell stage were recovered by flushing the oviducts of mated animals $48 \mathrm{~h}$ after hCG injection (day 2). Embryos at the eight-cell stage were collected from the oviduct and uterus $72 \mathrm{~h}$ after hCG administration and blastocysts were collected from the uterus approximately $96 \mathrm{~h}$ after hCG injection. In every case, embryos were collected in Hepes-HTF/BSA. Embryos were washed twice in bicarbonate-buffered human tubal fluid medium (Quinn et al., 1985) containing $3 \mathrm{mg}$ BSA $\mathrm{ml}^{-1}$ (HTFM/BSA). Embryos were transferred to the appropriate buffer on ice and then prepared for assay. Embryos were cultured from the one-cell stage in HTFM/BSA modified by the addition of 0.11 mmol EDTA $\mathrm{I}^{-1}$ and 1 mmol glutamine $\mathrm{I}^{-1}$. This medium was further supplemented with inhibitors or vehicle as indicated in individual experiments.

\section{Preparation of embryo extracts}

All operations were performed at $4^{\circ} \mathrm{C}$. Embryo extracts were

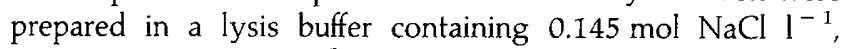
$10 \mathrm{mmol}$ Tris- $\mathrm{HCl} \mathrm{1^{-1 }}$ (pH 7.4), 1 mmol EDTA $\mathrm{I}^{-1}$ and $10 \mathrm{mmol} \mathrm{NaF} \mathrm{1^{-1 }}$ (Sigma Chemical Co.). Embryos were transferred in a minimal volume using a drawn Pasteur pipette to the buffer in a microfuge tube, giving a final concentration of between 5 and 14 embryos $\mu^{-1}$. The embryos were immediately sonicated on ice with a microtip probe on setting $I$ for $10 \mathrm{~s}$ (Heat Systems Ultrasonics W-385, NY). Aliquots of the mixture were used immediately.

\section{Preparation of mouse liver extracts}

The liver was removed, rinsed in isotonic saline $(0.9 \%, w / v)$ and homogenized in four volumes $\left(\mathrm{ml} \mathrm{g}^{-1}\right.$ liver) of isotonic saline with a hand homogenizer. The homogenate was centrifuged at $4^{\circ} \mathrm{C}, 13000 \mathrm{~g}$ for $15 \mathrm{~min}$ and the supernatant diluted I:64 with lysis buffer. Aliquots of the mixture were used immediately.

\section{CTP:phosphocholine cytidylyltransferase assay}

This assay was based on the method described by Vance et al. (1981), with modifications. All assays were performed in microtubes and incubated at $37^{\circ} \mathrm{C}$ with mixing in a shaking waterbath at 100 r.p.m. $\left[{ }^{14} \mathrm{C}\right]$ methyl phosphorylcholine was dried down under $\mathrm{N}_{2}$ and resuspended in lysis buffer to give a 5 -fold concentration ( $10 \mathrm{mmol} \mathrm{l}^{-1}, 50 \mathrm{mCi} \mathrm{mol}^{-1}$ ). Label was resuspended in $4 \mu \mathrm{l}$ Tris-succinate $\left(1 \mathrm{~mol} \mathrm{l^{-1 }} \mathrm{pH} 6.5\right), 2.5 \mu \mathrm{l}$ magnesium acetate $\left(120 \mathrm{mmol} \mathrm{l}^{-1}\right.$ ) and $2.5 \mu \mathrm{l} \mathrm{CTP}(40 \mathrm{mmol}$ 
$\mathrm{l}^{-1}$ ) (Sigma Chemical Co.). Aliquots of $2.8 \mu \mathrm{l}$ of this freshly prepared substrate mixture were added to each microtube (giving a final concentration of $\left[{ }^{14} \mathrm{C}\right]$ phosphorylcholine in the assay of $1 \mathrm{mmol} \mathrm{l}^{-1}$ ). The assay was initiated by the addition of $7.2 \mu \mathrm{l}$ embryo or liver extract to give a final assay volume of $10 \mu \mathrm{l}$. Assays were performed at least in duplicate with blank reactions containing aliquots of the lysis buffer without embryos. The reactions were stopped by placing tubes in boiling water for $2 \mathrm{~min}$. The reaction tubes were centrifuged at $4500 \mathrm{~g}$ for $10 \mathrm{~min}$ and the supernatant was subjected to TLC.

\section{Preparation of lipid suspensions}

L- $\alpha$-oleoyl-lysophosphatidylethanolamine was prepared to give final concentrations of $0.001-1000 \mu \mathrm{g} \mathrm{ml}^{-1}$ in the assay. Lipid was resuspended in lysis buffer by sonication with a microtip for $3 \mathrm{~min}$ at setting 1 . Serial dilutions were prepared and used immediately.

\section{TLC}

Each assay sample provided two $4 \mu \mathrm{l}$ aliquots for spotting on silica gel plates (Silica Gel G, Analtech). In addition, one blank reaction and one $\left[{ }^{14} \mathrm{C}\right]$ cytidinephosphocholine marker were spotted on each plate. The plates were developed in $\mathrm{CH}_{3} \mathrm{OH}: 0.6 \%(\mathrm{w} / \mathrm{v}) \mathrm{NaCl}: \mathrm{NH}_{4} \mathrm{OH}(60: 40: 5, \mathrm{v} / \mathrm{v} / \mathrm{v})$. After drying, the plates were scraped in $1 \mathrm{~cm}$ (vertical) $\times 2.5 \mathrm{~cm}$ (horizontal) sections into glass scintillation vials. To these were

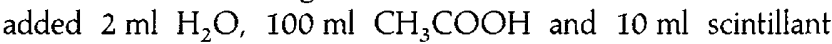
(Ecolite, ICN Biomedical, Costa Mesa, PA) and the amount of radioactivity in each fraction was determined. The distribution of radiolabel was compared with the CDP-choline marker and the CDP-choline production determined as the amount of radioactivity present after subtraction of the blank.

\section{Statistical analyses}

Results for statistical analysis were tested for normality using the Shapiro-Wilk test and then subjected to paired $t$ tests or one-way analysis of variance.

\section{Results}

An assay for CTP:phosphocholine cytidylyltransferase was developed for the preimplantation embryo, based on that described for the liver (Vance et al., 1981). The assay was scaled down to cope with the very small amounts of tissue available from the early embryo.

An activity was found that converted CTP and phosphocholine into CDP-choline. The activity was largely destroyed by boiling embryo homogenates for $15 \mathrm{~min}$ (Table 1). The production of CDP-choline increased in a linear fashion with increasing embryo number (18-118) in the homogenate (Fig. 1). Activity was approximately linear for 15-30 min, after which it began to slow (Fig. 2). These responses indicated that the production of CDP-choline was catalysed by an enzyme. On the basis of these observations, further characterization was performed with the equivalent of 30-60 embryos per reaction.
Table 1. Effect of various treatments on the activity of CTP:phosphocholine cytidylyltransferase in two-cell mouse embryos

\begin{tabular}{lc} 
Treatment & $\begin{array}{c}\text { Percentage of } \\
\text { control activity }\end{array}$ \\
\hline Boiling & $9.5 \pm 6.7^{* *}$ \\
Exclusion of $\mathrm{NaF}$ & $60.2 \pm 5.6^{*}$ \\
EDTA & $85.3 \pm 6.8$ \\
Concentration of $\mathrm{Ca}^{2+}$ in reaction buffer $\left(\mu \mathrm{mol} \mathrm{L}^{-1}\right)$ & \\
$\quad 1$ & $77.5 \pm 11.9$ \\
10 & $79.7 \pm 8.5$ \\
100 & $99.5 \pm 16.3$ \\
Removal of $\mathrm{Mg}^{2+}$ from reaction buffer & $19.9 \pm 1.06^{* *}$ \\
Exclusion of exogenous CTP & $2.87 \pm 2.03^{* *}$
\end{tabular}

The results shown are the activities detected following treatment compared with activities in homogenates from control (untreated) preparations, expressed as a percentage. Each value is the mean \pm SEM of at least three replicates. The activity within control embryos was $1.8 \pm 0.22 \mathrm{fmol}$ cytidine diphosphocholine produced per embryo $\min ^{-1}$ (mean \pm SEM).

$* P<0.05$ and $* * P<0.001$, compared with activity in controls.

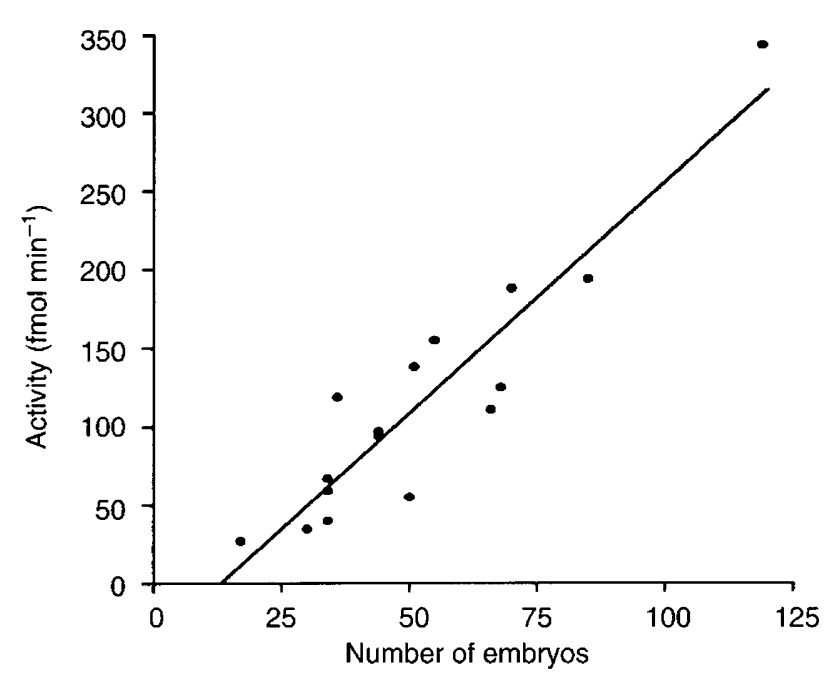

Fig. 1. The activity of CTP:phosphocholine cytidylyltransferase over a range of mouse embryo concentrations present in the reaction mixture. Each point is the mean of at least duplicate determinations.

Incubation was performed routinely for $90 \mathrm{~min}$. Although this was outside the linear range of the reaction, it was found that more time allowed enough product to form to give improved sensitivity and reliability in the assay. This was necessitated by the small number of cells available when using preimplantation embryos. Thus, estimates of specific activity may contain some inaccuracy due to this necessary compromise.

The reaction was found to be entirely dependent upon the addition of exogenous CTP (Table I), showing that this co-substrate neither accumulates to significant amounts in the early embryo nor is rapidly degraded following homogenization of embryos. $\mathrm{Mg}^{2+}$ was also essential for enzyme activity but $\mathrm{Ca}^{2+}\left(1-100 \mu \mathrm{mol} \mathrm{I}^{-1}\right)$ had no statistically significant effect (Table 1). The absence of $\mathrm{NaF}$ from the medium resulted in a significant reduction in enzyme activity (Table $\mathrm{I}$ ). $\mathrm{NaF}$ is a 


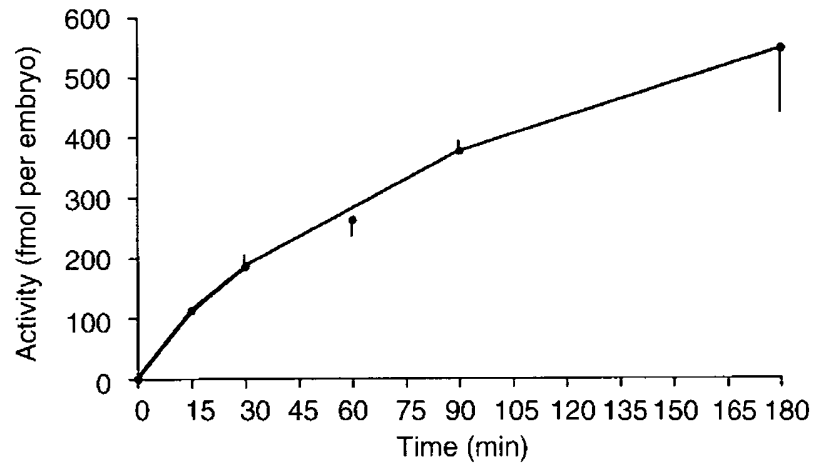

Fig. 2. The activity of CTP:phosphocholine cytidylyltransferase in two-cell mouse embryos over increasing durations of incubation. Each point is the mean ( \pm SEM) of three replicates, with the equivalent of 40 embryos per reaction. Each replicate was performed at least in duplicate.

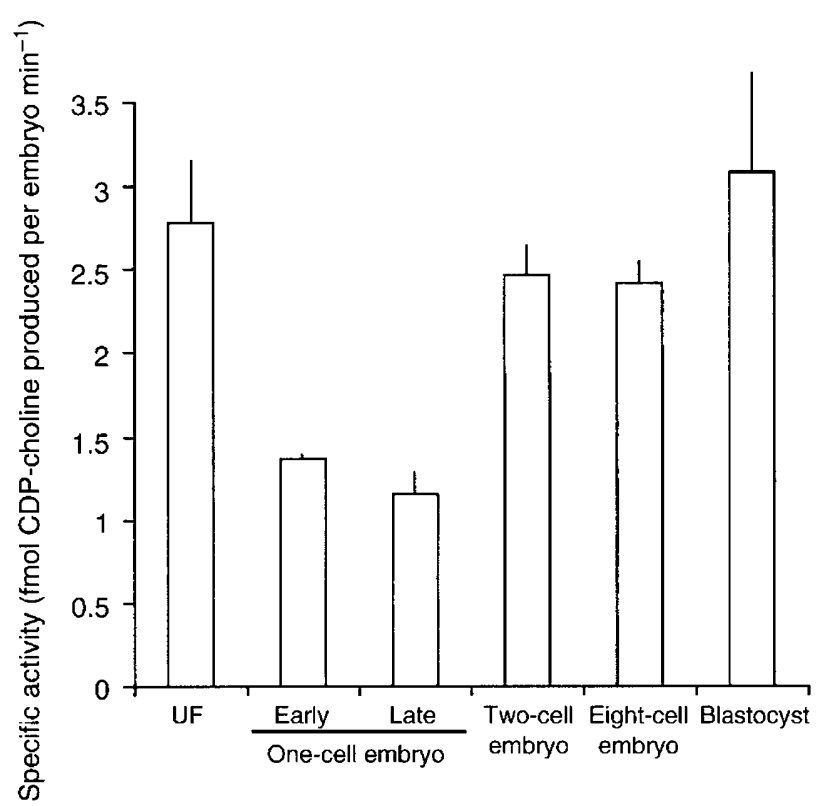

Fig. 3. The specific activity of CTP:phosphocholine cytidylyltransferase of oocyte and preimplantation embryos collected from the reproductive tract of mice at the developmental phases indicated. Each result is the mean (and SEM) of at least three different experiments. UF: unfertilized oocytes. CDP-choline: cytidine diphosphocholine.

phosphatase inhibitor and its actions suggest that the phosphorylation status of the enzyme is important for its activity in the embryo and that there were phosphatases present within the embryo capable of acting on the enzyme. Alternatively, it is possible that phosphatases act to degrade choline-phosphate activity causing substrate limitation.

Estimates of specific activity of the enzyme were made for the unfertilized oocyte, the zygote and embryos during the preimplantation phase (Fig. 3). There was no difference $(P>0.05)$ in the specific activity between the unfertilized oocyte and embryos from the two-cell to the blastocyst stage. This represents a major reduction in activity when expressed on a per-cell basis. The mouse blastocyst contains approximately 80 cells. Thus, development from the two-cell to the blastocyst stage results in a reduction in activity per cell by a factor of approximately 40 .
Table 2. Effect of exogenous lipid on the activity of CTP: phosophocholine cytidylyltransferase [fmol cytidine diphosphocholine produced per oocyte (or embryo) $\mathrm{min}^{-1}$ ]

\begin{tabular}{lcc}
\hline & Control & $\begin{array}{c}\text { Lipid }\left(\mathrm{I} \mu \mathrm{g} \mathrm{ml}^{-1}\right) \\
(\text { mean } \pm \mathrm{SEM})\end{array}$ \\
\hline Two-cell embryos & $2.50 \pm 0.53$ & $3.96 \pm 0.46^{*}$ \\
Unfertilized oocytes & $2.78 \pm 0.46$ & $3.28 \pm 0.55^{*}$ \\
One-cell embryos & $1.34 \pm 0.38$ & $1.41 \pm 0.22^{* *}$ \\
\hline
\end{tabular}

Each result is based upon at least three replicates.

$* P<0.01$ and $* * p>0.05$, compared with corresponding controls.

The total protein content of the embryo does not change greatly during the preimplantation phase (Schiffner et al., 1976), with zygotes having $24.5 \pm 6.5 \mathrm{ng}$ protein (mean \pm SEM), which decreases to $20.9 \pm 5.0 \mathrm{ng}$ in morulae and returns to $24.8 \pm 6.2 \mathrm{ng}$ in early blastocysts. Therefore, in blastocysts, the specific activity of cytidylyltransferase was $0.124 \mathrm{nmol}$ CDPcholine $\mathrm{min}^{-1} \mathrm{mg}^{-1}$ protein, which is comparable to that found in the liver $\left(0.7 \mathrm{nmol}\right.$ CDP-choline $\left.\min ^{-1} \mathrm{mg}^{-1}\right)$.

The specific activity of cytidylyltransferase in fertilized oocytes was markedly lower (by about $50-60 \%)(P<0.01)$ than that of unfertilized oocytes of an equivalent age and also lower than later-stage embryos. This was the case for zygotes soon after fertilization (early, i.e. just after pronucleus formation, $21 \mathrm{~h}$ after $\mathrm{hCG}$ injection) and also just before syngamy (late, i.e. $30 \mathrm{~h}$ after hCG injection).

The cytidylyltransferase identified in a variety of other tissues is characterized by its activation by lipids. Lysophosphatidylethanolamine ( $1 \mathrm{mg} \mathrm{m}{ }^{-1}$ ) has been found to be particularly potent in this regard for rat liver cytidylyltransferase (Choy and Vance, 1978). To validate procedures, the effect of exogenous lipid on rat liver cytidylyltransferase activity was assessed in the microsomal fraction of liver homogenates. The addition of $1 \mathrm{mg}$ lysophosphatidylethanolamine $\mathrm{ml}^{-1}$ to the preparation increased the specific activity from $0.70 \mathrm{nmol}$ CDP-choline $\mathrm{min}^{-1} \mathrm{mg}^{-1}$ protein to $2.44 \mathrm{nmol} \mathrm{min}^{-1} \mathrm{mg}^{-1}$.

In preliminary experiments with embryo homogenates, it was shown that the addition of lysophosphatidylethanolamine at a concentration of $0.1-1 \mathrm{mg} \mathrm{ml}^{-1}$ inhibited enzyme activity. Maximum enzyme activity in embryos was detected at a lipid concentration of $1 \mu \mathrm{g} \mathrm{ml}^{-1}$. The inhibitory effect at high lipid concentrations was likely to be due to detergent-like effects of the lipid relative to the small amounts of material present in embryo homogenates. This hypothesis was supported by the observation that the addition of 0.3 or 3 mmol Triton X-100 $\mathrm{l}^{-1}$ to homogenates inhibits enzyme activity (results not shown).

Cytidylyltransferase activity at various stages of embryo development was assessed (Table 2) using $1 \mu \mathrm{g}$ lysophosphatidylethanolamine $\mathrm{ml}^{-1}$. The presence of lipid in the reaction caused a significant increase in cytidylyltransferase activity in both two-cell and unfertilized oocytes. By contrast, the activity in fertilized oocytes was unaffected by the presence of lipid.

The increase in cytidylyltransferase activity from the onecell to the two-cell stage occurred at a time when the first 
Table 3. Effect of treating mouse zygotes with various inhibitors on the specific activity of CTP:phosophocholine cytidylyltransferase (mean \pm SEM)

\begin{tabular}{llc}
\hline & \multicolumn{2}{c}{$\begin{array}{c}\text { Specific activity } \\
\text { [fmol cytidine diphosphocholine } \\
\text { produced per embryo min }\end{array}$} \\
\cline { 2 - 3 } & Control & Inhibitor \\
\hline a-Amanitin & $2.52 \pm 0.08$ & $2.34 \pm 0.13$ \\
Cycloheximide & $1.84 \pm 0.12$ & $1.98 \pm 0.17$ \\
H-7 & $2.29 \pm 0.36$ & $2.25 \pm 2.25$ \\
\hline
\end{tabular}

H-7, [1-(5-isoquinolinesulfonyl)-2-methylpiperazine, $\mathrm{HCl}]$ dihydrochloride.

transcription from the zygotic genome is reported to occur. To determine whether transcription of new mRNA for cytidylyltransferase occurred at this time, one-cell embryos were collected and cultured for $18 \mathrm{~h}$ in the presence of $\alpha$-amanitin $\left(11 \mu \mathrm{g} \mathrm{ml}^{-1}\right)$, which is a selective inhibitor of RNA polymerase II. This treatment had no effect on the expected increase in cytidylyltransferase activity (Table 3 ). In experiments of similar design, the protein synthesis inhibitor cycloheximide $(10 \mu \mathrm{g}$ $\left.\mathrm{ml}^{-1}\right)$ and the protein kinase inhibitor $\mathrm{H}-7\left(18 \mu \mathrm{g} \mathrm{ml}^{-1}\right)$ were also without effect (Table 3). Cycloheximide, $\alpha$-amanitin and H-7 treatment blocked cell division at the concentrations used in the study.

\section{Discussion}

This report provides the first description of the enzyme CTP:phosphocholine cytidylyltransferase (EC 2.7.7.15) in the mammalian oocyte and preimplantation embryo. The activity can be assigned to an enzyme, since activity was lost following boiling of the embryo homogenate; it was dependent on time and the concentration of embryos and required the co-substrate CTP. The reactions were performed at saturating concentrations of CTP and phosphorylcholine (Vance et al., 1982). The dependence of the enzyme on $\mathrm{Mg}^{2+}$ and the ability of exogenous lipid to activate it show that embryonic cytidylyltransferase shares these characteristics with the enzyme from other mammalian sources, such as the rat liver (Choy and Vance, 1978; Vance et al., 1981).

Total cytidylyltransferase activity remained relatively constant in oocytes and preimplantation embryos except for an apparent decline following fertilization. This decline in activity was accompanied by a loss in the ability of exogenous lipid to enhance its activity in vitro. This contrasted with the situation for unfertilized oocytes and two-cell embryos, both of which showed a significant increase in activity following the addition of $1 \mu \mathrm{g}$ lysophosphatidylethanolamine $\mathrm{ml}^{-1}$. Thus, fertilization was associated with a decrease in the inherent activity of the enzyme as well as a loss of its ability to be activated to the lipid-bound form. The subsequent increase in cytidylyltransferase activity at the two-cell stage was independent of transcription, protein synthesis or protein phosphorylation (which could be inhibited by relatively high concentrations of the protein kinase inhibitor $\mathrm{H}-7$ ). The inhibitors tested (cycloheximide, $\alpha$-amanitin and H-7) also blocked the progression of embryos to the two-cell stage, although cytidylyltransferase activity in such embryos was equivalent to that in normal two-cell embryos. This suggests that the increased activity was independent of cell-cycle-dependent kinases. These observations suggest that both the reduction and subsequent increase in cytidylyltransferase activity may not have been due to a decrease in the absolute amount of enzyme in one-cell embryos but rather due to an inhibition of its activity that was reversed at the two-cell stage.

In two-cell embryos and unfertilized oocytes, the extent of activation of the enzyme by exogenous lipid was modest compared with that reported in other cells (Choy and Vance, 1978) and our observation with mouse liver. This suggests that within embryo homogenates most of the enzyme was membrane-bound. This conclusion is consistent with the inhibition of activity observed in the presence of detergent concentrations of lysophosphatidylethanolamine or Triton $X-100$. As a result, there may be limited capacity for acute upregulation of enzyme activity by translocation of soluble enzyme to the membrane, while downregulation might be rapidly induced by dissociation from membranes. The constant activity throughout the preimplantation phase (with the exception of a transient decline at the one-cell stage), together with the absence of any effect of transcription and protein synthesis inhibitors, suggest that the enzyme present in the oocyte remains during early development and is partitioned among the daughter cells during early embryo development. Cytidylyltransferase (both membrane and soluble) is located within the nucleus (Chu, 1994), which may facilitate such partitioning during mitoses.

The relatively constant total cytidylyltransferase activity observed from the two-cell to the blastocyst stage occurred despite a reported (Pratt, 1980) 13-fold increase in the incorporation of $\left[{ }^{14} \mathrm{C}\right]$ methyl choline in phospholipids during this same period. During this phase of development, the rate of phospholipid synthesis from choline approximately doubled on a per-cell basis (Pratt, 1980), while the cytidylyltransferase activity declined by approximately 40 times on a per-cell basis. Therefore, it is likely that the total amount of cytidylyltransferase is more than sufficient to meet the needs of the embryo during the preimplantation phase and that regulation of this reaction is exerted at a level other than cytidylyltransferase concentration. These results are in contrast with the evidence of pulse-chase studies (Pratt, 1980) using $\left[{ }^{14} \mathrm{C}\right]$ methylcholine, which showed that choline does not accumulate as CDPcholine, showing that the cytidylyltransferase reaction is not in equilibrium within intact embryos.

Studies in other cell types suggest that regulation of activity may be due to the enzyme's amphitrophism or its phosphorylation status. Activity can be modulated by multiple phosphorylation-dephosphorylation reactions (Houweling et al., 1994). There are consensus phosphorylation sites for cAMP-dependent kinase and the enzyme also contains a zinc finger (Kalmar et al., 1990). The region spanning amino acids 237-314 contains the lipid-binding domain, which constitutes an inhibitory segment over the catalytic domain (Kalmar et al., 1990). This inhibitory effect is reversed by the binding of lipid. The inhibition causes the enzyme to have a low affinity for its 
co-substrate CTP $\left(K_{\mathrm{m}}\right.$ value of $24.7 \mathrm{mmol} \mathrm{l}^{-1}$ ) (Yang et al., 1995). This affinity is increased $\left(K_{\mathrm{m}}\right.$ value of $\left.0.7 \mathrm{mmol} \mathrm{l}^{-1}\right)$ upon lipid binding. The affinity of the enzyme for its other substrate, phosphocholine, is unaffected by lipid binding.

Activity can be affected by the affinity of the enzymes for substrate but also by the concentration of the substrates achieved within cells. The enzyme has two co-substrates: CTP and phosphorylcholine. In this study, it was shown that CDP-choline was not formed in embryo homogenates in the absence of exogenous CTP, suggesting that this substrate may not accumulate to a significant degree in the embryo. The intracellular CTP concentration may limit cytidylyltransferase activity (McDonough et al., 1995) in some cells, since overexpression of CTP synthetase causes increased CDP-choline synthesis. There is limited information on the size of the endogenous pool of CTP in the early embryo but its apparent absence (or unavailability for reaction) in fresh embryo homogenates suggests that it may be one important regulator of cytidylyltransferase activity in embryos.

The observation that feeding embryos $\left[{ }^{14} \mathrm{C}\right]$ methyl choline results in the significant accumulation of $\left[{ }^{14} \mathrm{C}\right]$ cholinephosphate (Pratt, 1980) suggests that the production of this substrate may not be a significant regulatory step in cytidylyltransferase activity. Knowledge of the $K_{\mathrm{m}}$ value for embryonic cytidylyltransferase for cholinephosphate and quantification of the endogenous cholinephosphate pool in embryos is required to confirm this. The endogenous choline pool in mammalian embryos has not been analysed, although it is high in sea urchin embryos (Pasternak, 1973). Furthermore, the embryo has a membrane choline transporter (Van Winkle et al., 1993) and the activity of choline kinase increases significantly throughout early embryo development (Pratt, 1980).

This study shows that the oocyte and early embryo contain a CTP:phosphocholine cytidylyltransferase similar to that previously described in mammalian somatic tissue. It is characterized by its dependence on $\mathrm{Mg}^{2+}$ and its activation of lipids. The total potential activity of cytidylyltransferase in the early embryo does not appear to be limiting in the early embryo; thus, regulation of the synthesis of choline-containing phospholipids at this reaction must occur via other mechanisms.

\section{References}

Blank ML, Lee YJ, Cress EA and Snyder F (1988) Stimulation of the de novo pathway for the biosynthesis of platelet-activating factor (PAF) via cytidylyltransferase activation in cells with minimal endogenous PAF production Journal of Biological Chemistry 263 5656-5661
Choy PC and Vance DE (1978) Lipid requirements for activation of CTP:phosphocholine cytidylyltransferase from rat liver Journal of Biological Chemistry 253 5163-5167

Chu AJ (1994) Mechanism by which ethanol inhibits phosphatidylcholine biosynthesis in human leukemic monocyte-like U937 cells Cell Biochemistry and Function 12 45-55

Houweling M, Jamil H, Hatch GM and Vance DE (1994) Dephosphorylation of CTP-phosphocholine cytidylyltransferase is not required for binding to membranes Journal of Biological Chemistry 269 7544-7551

Kalmar GB, Kay RJ, Lachance A, Aebersold R and Cornell RB (1990) Cloning and expression of rat liver CTP:phosphocholine cytidylyltransferase: an amphipathic protein that controls phosphatidylcholine synthesis Proceedings of the National Academy of Sciences, USA 87 6029-6033

Lee T, Malone B, Blank ML, Fitzgerald V and Snyder F (1990) Regulation of the synthesis of platelet-activating factor and its inactive storage precursor (1-alkyl-2-acyl-sn-glycero-3-phosphocholine) from 1-alkyl-2-acetyl-snglycerol by rabbit platelets Journal of Biological Chemistry 265 9181-9187

McDonough VM, Buxeda RJ, Bruno ME, Ozier-Kalogeropoulos O, Adeline MT, McMaster CR, Bell RM and Carman GM (1995) Regulation of phospholipid biosynthesis in Saccharomyces cerevisiae by CTP Journal of Biological Chemistry $27018774-18780$

O'Neill C (1985) Partial characterisation of the embryo-derived platelet activating factor in mice Journal of Reproduction and Fertility 75 375-380

Pasternak CA (1973) Phospholipid synthesis in cleaving sea urchin eggs: model for specific membrane assembly Developmental Biology 30 403-410

Pratt HM (1980) Phospholipid synthesis in the preimplantation mouse embryo Journal of Reproduction and Fertility 58 237-248

Quinn P, Warnes GM, Kerin JF and Kirby C (1985) Culture factors affecting the success rate of IVF and embryo transfer Annals of the New York Academy of Sciences 442 195-199

Rutherford MS, Rock CO, Jenkins NA, Gilbert DJ, Tessner TG, Copeland NG and Jackowski S (1993) The gene for murine CTP:phosphocholine cytidylyltransferase (Ctpct) is located on mouse chromosome 16 Genomics 18 698-701

Sundler R and Akesson B (1975) Regulation of phospholipid biosynthesis in isolated rat hepatocytes. Effect of different substrates Journal of Biological Chemistry 250 3359-3367

Van Winkle LJ, Campione AL, Mann DF and Wasserlauf HG (1993) The cation receptor subsite of the choline transporter in preimplantation mouse conceptuses resembles a cation receptor subsite of several amino acid transporters Biochimica et Biophysica Acta 1146 38-44

Vance DE, Pelech SD and Choy PC (1981) CTP:phosphocholine cytidylyltransferase from rat liver Methods in Enzymology 71 576-581

Wells XE and O'Neill C (1992) Biosynthesis of platelet-activating factor by the mouse two-cell embryo Journal of Reproduction and Fertility 96 6I-71

Wells XE and O'Neill C (1994) Detection and preliminary characterization of two enzymes involved in biosynthesis of platelet-activating factor in mouse oocytes, zygotes and preimplantation embryos: dithiothreitol-insensitive cytidinediphospho-choline:I-o-alkyl-2-acetyl-sn-glycerol cholinephosphotransferase and acetyl-coenzyme A:I-o-alkyl-2-lyso-sn-glycero-3phosphocholine acetyltransferase Journal of Reproduction and Fertility 101 385-391

Yang W, Boggs KP and Jackowski S (1995) The association of lipid activators with the amphipathic helical domain of CTP:phosphocholine cytidylyltransferase accelerates catalysis by increasing the affinity of the enzyme for CTP Journal of Biological Chemistry $27023951-23957$ 